\title{
FDI and International Trade: A Review
}

\author{
Xintong $\mathrm{Li}^{1, *}$ \\ ${ }^{1}$ Shandong shiyan middle school, No.73 Jingqi Road, Shizhong District, Jinan City, Shandong Province,China \\ *Xintong Li.Email: xintong000126@163.com
}

\begin{abstract}
As an important aspect of globalization, FDI (Foreign Direct Investment) has always been an important topic that cannot be overlooked in international trade theory. Based on the classical theory, this paper sorts out many outstanding studies on FDI. Research suggests that the main incentives for companies' different forms of foreign investment are different. Among them, horizontal FDI is a trade-off between trade costs and the fixed costs of factory construction, while the main purpose of vertical FDI is to reduce production costs by cashing in on the comparative advantages of different countries. Another angle to study FDI is to ascertain the boundaries of enterprises. The results show that products with different characteristics will make enterprises have different choices of vertical integration and outsourcing. FDI has a variety of economic effects. Technology spillover effects have different impacts on the productivity of enterprises, while the market integration resulting from direct foreign investment can also provide enterprises with multi-dimensional profit increases.
\end{abstract}

\section{Keywords: FDI, Trade}

\section{INTRODUCTION}

Foreign direct investment (FDI) still plays an important role in the economy of developing countries. In recent years, FDI in developed countries has shown a downward trend, but developing countries have maintained a steady growth rate. Developing countries accounted for $54 \%$ of global FDI flows in 2019, accounting for more than half of the increase from less than $30 \%$ in the wake of the financial crisis. FDI is an important source of R\&D investment of enterprises, and about $50 \%$ of $R \& D$ in the world is generated through FDI. On the other hand, FDI by MNCs contributes to a significant flow of foreign trade: in 2017, about one-third of global foreign trade was intra-firm trade, and MNCs also participated in another third of international trade as participants. Such a great economic role has caused economists to continuously explore FDI, and research results on FDI behavior from new trade theories have emerged one after another. For the largest emerging economy in the world, China has experienced rapid increasing FDI and OFDI in last 10 years. Figure 1 shows total FDI in China from 2012 to 2018. In 2018, China's total FDI reached $\$ 20121 \mathrm{~m}$, which was about four times that of 2012. These huge capital flows are accompanied by the rapid growth of China's economy, as well as the dramatic changes in China's economic structure. In 2018, the inflow of foreign direct investment was US $\$ 13,781 \mathrm{~m}$, while the outflow of FDI was $\$ 6431 \mathrm{~m}$. With the deepening of economic globalization and China's continuous expansion and opening up, capital flow has become more comfortable than it was 7 years ago. In this paper, the theoretical and empirical articles that have made important contributions to the FDI theory are reviewed through a literature review.

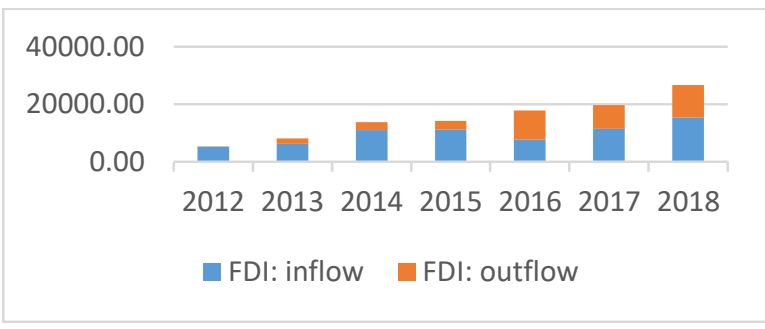

Figure 1 China total FDI,2012-2018 Data source: CEIC

Traditional trade theory focuses on merchandise trade but ignores investment as an important way to serve foreign markets. The investment behavior of firms that replicate a similar production task in another country is called horizontal direct investment (HDI), and research has found a substitution relationship between HDI and exports. However, with the increasing globalization process, factor price differences between countries have prompted multinational enterprises to outsource upstream production processes abroad or to invest 
directly to establish production plants in foreign countries where they have a comparative advantage, and this type of vertical investment has greatly contributed to the development of trade in intermediate goods.

FDI also has significant economic effects. The other direction of FDI's technology spillovers is the impact on home country firms. By stimulating home country firms to invest in $\mathrm{R} \& \mathrm{D}$, the innovation capacity of home country firms is increased. At the same time, a subsidiary located in a foreign market can effectively gain access to intangible assets such as local sales networks, technology, and knowledge, generating a technology spillover effect to the parent company. Also, mergers and acquisitions are an important source of economic effects. By merging upstream and downstream industries, firms can reduce production costs through internal marginal cost transactions, while gaining monopoly profits externally.

The rest of this paper will examine the outward FDI behavior of enterprises separately: the second part will examine the theoretical research results of horizontal and vertical FDI and the resulting theory of understanding enterprise boundaries from the property rights perspective; the third part will examine the economic effects of FDI from the perspectives of technology spillovers and mergers. And the fourth part will analyse the determined elements of FDI. The fifth part is conclusion.

\section{HORIZONTAL FDI AND VERTICAL FDI}

Theoretically, FDI can be categorized as horizontal FDI and vertical FDI based on the characteristics of enterprises' foreign investment business. The so-called horizontal FDI refers to an enterprise transferring the same business to foreign countries, and trading with it has a substitution relationship. Vertical FDI on the other hand refers to the external transfer of different upstream and downstream businesses within the industry. Generally speaking, horizontal FDI is a trade-off between trade cost and fixed cost of factory constructions. The higher the trade cost, the more likely companies are to reduce the dispersion of investment and save costs. Fixed costs are related to economies of scale. If a foreign investment can bring economies of scale, then it is obvious that FDI is the rational choice of enterprises.

\subsection{Horizontal FDI}

Brainard (1997) [1] is a relatively classic early study on horizontal FDI. Based on a simple model of twocountry, single-factor, multi-sector, he verified the influencing factors of horizontal FDI from four perspectives: trade cost, economies of scale, and national resource endowment. Among them, the trade cost is consistent with the content above, and in terms of economies of scale, he analyzes it from two perspectives.
First of all, the smaller the scale-incremental effect of the product, that is, the lower the fixed costs of product production, sales, $R \& D$, and advertising, the more profitable it is for an enterprise to carry out FDI. Secondly, the greater the economies of scale of a company, the more quickly the establishment of a factory overseas will reduce the average cost of the company, and it will also prompt the company to embrace the same strategy. He also analyzed the role of resource endowments in two countries. It is clear that since the types of products in horizontal FDI are the same, the smaller the difference in endowments between countries means the smaller the difference in the cost of producing the same product, so there will be more FDI behaviors, thus resulting in the promotion of the so-called "North-North Trade." Markusen \& Venables (1998, 2000) [2][3] extended Brainard (1997) to the case of two factors, and the results were consistent. The more similar the endowments of the two countries, the higher the GDP, the higher the probability of FDI. In the subsequent discussions on the heterogeneity of enterprises, Helpman, Melitz \& Yeaple (2004) [4] established a model of enterprise heterogeneity, laying the foundation for the "New New Trade Theory", and found that the most productive enterprises engage in FDI, the second most productive enterprises can undertake export business, and enterprises with productivity further down will be engaged in domestic sales, and the least productive enterprises will exit the market.

\subsection{Vertical FDI}

Helpman (1984) [5]carried out pioneering work on vertical FDI. Based on the H-O framework, the article divides product production into two phases: headquarters and output. The headquarters service is characterized by technology-intensive, and the output phase is laborintensive. Due to differences in endowments between countries, according to the traditional theory of comparative advantage, there will be work specialization within the industry of multinational companies, that is, vertical FDI. Moreover, the greater the difference in endowment among countries, the more the vertical FDI. Yeaple (2003)[6] further studied industry characteristics. Taking the United States as an example, FDI in laborintensive industries will flow more to China than to Europe, while capital-intensive industries will be the opposite. Hanson, Mataloni \& Slaughter (2005)[7] conducted a rigorous empirical test on intermediate trade using US corporate data. They found that vertical FDI is closely related to intermediate trade and processing trade. Hanson, Mataloni \& Slaughter (2001) [8]employed the same data to accurately distinguish between the subsidiary-parent company trade and the independent trade of the subsidiaries and found that both vertical FDI and horizontal FDI exist, but vertical FDI is showing an increasing trend. 


\subsection{Enterprise Boundary Theory}

The focus of enterprise boundary theory research is no longer on the production and the place of the firm's products, but the ownership relationship between the producer of intermediate goods and the parent company during the production process. If the upstream firm is controlled by the downstream firm, it is vertical integration, and the opposite is the corresponding outsourcing behavior. The trade-off between vertical integration and outsourcing is the transaction cost (Antras (2003), Antras \& Helpman $(2004,2008)$ )[9][10][11]. The headquarters of an enterprise is a technology-intensive part of the production; hence it will incur smaller production costs for technology-intensive products, and therefore it is reasonable to match it with greater decision-making power, which is the incentive for vertical integration. On the other hand, due to the issue of incomplete contracts in production activities, countries with weaker market supervision have weaker contract protection. Once the upstream intermediate products have quality problems, downstream companies will suffer tremendous losses. Another important reason is the specialization of intermediate products. Regardless of intermediate product manufacturers or final product manufacturers, it is difficult to sell intermediate products to enterprises in other sectors after production. To avoid the profit risk brought by this kind of specialized production, both upstream and downstream companies have incentives to deviate from the original contract, which creates the problem of incomplete contracts. To avoid the above-mentioned hold-up problem, downstream companies tend to choose to adopt a vertical integration strategy for technology-intensive products, while an outsourcing strategy for labor-intensive products.

\section{THE ECONOMIC EFFECT OF FDI}

\subsection{Technology Spill Over Effect}

The influx of foreign capital often comes with higher production technology and management experience, therefore promoting the total factor productivity of the domestic market. This effect is called the technology spillover effect of FDI. Early literatures have conducted empirical tests on this technology spillover effect at the industrial level (Blomstrom (1986), Blomstrom and Persson(1983), Kokko(1994), Blomstrom and Sjoholm (1999))[12][13][14][15]. These studies have found that FDI can indeed improve the productivity of relevant industries in the destination country, however, there are two ways to cast influence. One is that the new technology and management experience brought about by FDI provides a better direction for technological learning and innovation for industries in the destination country, thereby improving total factor productivity; the other is due to the higher total factor productivity of foreign enterprises themselves. The fierce market competition at the same time eliminates low-productivity companies in the destination country, increasing overall industry productivity. However, the spillover effect of FDI in empirical research has not always been optimistic. Aitken \& Harrison (1999)[16] used Venezuelan data to find that the FDI brought in by Venezuela inhibited Venezuela's industrial productivity.

Another direction of the technology spillover effect of FDI is the impact on the home country company (parent company). Most articles find that direct foreign investment will increase the productivity of enterprises, but there are also studies showing that there is no significant correlation between the two. Desai et al. (2005)[17] argue that outward foreign direct investment (OFDI) stimulates the R\&D investment of home country companies, thus improving the innovation capabilities of home country companies and increasing the company's total factor productivity. $\mathrm{Li}$ and $\mathrm{Hu}(2010)[18]$ used data from Taiwan, China, and found that OFDI of Taiwanese companies to the mainland also had a positive impact on their innovation capabilities. Pradhan \& Singh (2009)[19] used OFDI data in the Indian auto industry to find that the innovation capabilities of Indian outbound-invested auto companies have been significantly strengthened through exposure to foreign technologies and markets. Blonigen (1997) [20]studied Japan's mergers and acquisitions of American auto companies. They found that the M\&As of Japanese companies could effectively enable the parent company to acquire intangible assets such as the sales network, technology, and knowhow of U.S. auto companies, resulting in technology spillover effects on the parent company.

\subsection{Market Integration}

Enterprises can reduce the monopoly power of upstream companies through OFDI behavior through vertical integration, thereby reducing production costs and obtaining higher profits (Horstman \& Markusen (1992))[21]. Feenstra \& Hamilton (2003) [22]further explained the economic effects of FDI from the perspective of group companies, arguing that companies can trade at marginal costs within the group through integration and create monopoly prices externally.

FDI can reduce information asymmetry by entering the market. Markusen (2001)et al. [23]argue that companies will face the dilemma of foreign brand quality information being not accepted when entering external markets. Hence, they need local companies to help them promote. To reduce the issue of moral hazard in the principal-agent relationship, companies will adopt the method of profit sharing. If profit sharing is too high, it will be transformed into direct foreign investment behavior. 


\section{ANALYSIS OF FACTORS AFFECTING FDI}

Theoretical studies on multinational enterprises began with the monopoly advantage theory, and then international investment theories such as product life cycle theory, marginal product expansion theory, internalization theory, and international production tradeoff theory have been enriched to provide the theoretical basis for enterprises' overseas investment. Specifically, two main factors can be isolated: excess profit acquisition and production cost reduction. The least-cost industrial location theory provides theoretical guidance for the location choice of multinational companies, and introduces three location factors: freight, wages and agglomeration to analyze the layout of enterprise investment. For labor-intensive enterprises, wage cost is an important factor affecting their production cost. If the wage cost in foreign countries is lower than that in China, the lower wage level makes the investment in that country more profitable, and at this time, enterprises are more inclined to invest across borders, and the location of cross-border investment may change with the change of labor supply situation.

Earlier scholars have studied the factors affecting FDI entry based on macro data. Based on the actual situation in developed countries, Hymer (1978) [24]proposed the theory of monopoly advantage. Buckley (2016)[25] argues that the key mechanism for firms to make FDI in host countries is to convert external market transactions into internal market transactions, thus reducing the additional costs of intermediate goods transactions and market uncertainty. Dunning (1977)[26] further refines the advantages of firms, which he summarizes as location advantages, ownership advantages, and internalization advantages. In fact, FDI is not only limited to exports from developed to developing countries, but also a large number of developing countries make capital investments in developed countries. Wells (1977) [27]explain the lower part of the chain of direct outward investment from developing countries, arguing that developing countries make profits by occupying niche demand in developed markets, through small-scale production of services and skilled technology. Lall (1985)[28] complements Wells' (1977) study. Acknowledging the standardized and laborintensive technological characteristics of developing country MNEs, he further suggests the achievements of these MNEs in absorbing technology from the surrounding market environment and in their own technological adaptation. Cantwell (1990) [29] also finds the fact that direct investment from emerging economies to developed economies further contributes to the upgrading of domestic industries.

Another literature analyzes the impact of labor costs on FDI. studies such as Yin, Yufei (2014)[30] argue that rising labor costs inhibit FDI entry, arguing that rising labor costs increase firms' costs and weaken FDI investment intentions. In contrast, Mody and Srinivasan (1998)[31]; Akinlo (2004)[32] view labor costs as a signal to identify the human capital and market potential of a market, and thus promote FDI inflows when labor costs rise. In a related empirical study, Wang and Swain (1997) [33] found a significant positive relationship between wage level and FDI. The minimum wage system implemented in the host country similarly affects the inflow of external capital. Theoretically, on the one hand, the cost effect of the minimum wage will inhibit FDI entry. Minimum wage increases drive up the average wage of firms (Dube et al. (2010)[34]). The minimum wage increase not only directly raises the wages of lowincome employees who were below the minimum wage (Ma et al., 2012)[35], but also raises the income of highincome workers through a "spillover effect" to maintain the pay gap (Duan, Zhimin, and Hao, Feng, 2019)[36]. On the other hand, minimum wage increases can force firms to increase productivity and promote FDI entry. Minimum wage hikes not only directly motivate employees to work, but also prompt firms or employees to enhance professional skills training, improve human capital levels, and ultimately increase firms' labor productivity. Although MNCs will only transfer low value-added segments of their products to developing countries for technical protection reasons, these production segments still require certain skills of workers, and FDI firms are willing to attract skilled workers with high wages. Mody and Srinivasan (1998) study MNCs in the United States and Japan, Akinlo (2004) study Mody and Srinivasan (1998) study US and Japanese multinationals, and Akinlo (2004) study FDI in Nigeria, both find that labor quality significantly and positively affects FDI.

The income distribution effect of the minimum wage promotes FDI entry. Minimum wage increases directly raise the incomes of low-income households, while raising the incomes of high-income households through spillover effects. Income and consumption are generally positively correlated. Zhang Jun et al. (2017)[37] find that the increase in minimum wage has a significant stimulating effect on consumption expenditure, with each $10 \%$ increase expected to increase urban residents consumption by about 1.167 billion yuan in four regions, namely Guangdong, Shanghai, Sichuan and Liaoning. Thus, the minimum wage increase somehow reflects the increased consumption capacity and market size or potential of the region, which is undoubtedly attractive to FDI committed to exploring the local market.

\section{CONCLUSION}

The main incentives for different forms of outward investment differ between firms. Whereas horizontal FDI is a trade-off between trade costs and fixed costs of plant construction, the main purpose of vertical FDI is to reduce production costs by taking advantage of the comparative advantages of different countries. Another 
entry point for studying is the determination of firm boundaries, where it is found that products with different characteristics give rise to different choices between vertical integration and outsourcing, that there are multiple economic effects of FDI, that technology spillovers have different effects on firm productivity, and that market integration through direct foreign investment can also provide multiple profit increases for firms.

\section{REFERENCES}

[1] Brainard, S. Lael (1997). An Empirical Assessment of the Proximity-Concentration Trade-off Between Multinational Sales and Trade, American Economic Review, 87:4, pp. 520-544.

[2] Markusen J. and A. Venables (1998): Multinational Firms and the New Trade Theory., Journal of International Economics, 46(2), 183-203.

[3] Markusen, James R., and Anthony J. Venables (2000). The Theory of Endowment, Intra-industry, and Multi-national Trade,. Journal of International Economics, 52, pp. 209-234.5

[4] Helpman, Elhanan, Marc J. Melitz, and Stephen R.Yeaple (2004),.Exports versus FDI with Heterogeneous Firms, .American Economic Review, 94:1, pp. 300-316.

[5] Helpman, Elhanan (1984). A Simple Theory of International Trade with Multinational Corporations., Journal of Political Economy, 92:3, pp. 451-471.

[6] Yeaple, Stephen (2003). The Role of Skill Endowments in the Structure of U.S.Outward FDI, Review of Economics and Statistics, August, 85(3), pp. 726-734.

[7] Hanson, G., Mataloni Jr., R., Slaughter, M., (2005). Vertical Production Networks in Multinational Firms. The Review of Economics and Statistics 87 (4), 664-678.

[8] Hanson G., Mataloni R., and M. Slaughter (2001). Expansion Strategies of U.S. Multinational Firms," in Dani Rodrik and Susan Collins, eds., Brookings Trade Forum 2001, pp. 245-282.

[9] Antràs, Pol (2003). Firms, Contracts, and Trade Structure, Quarterly Journal of Economics, 118:4, pp. 1375.1418 .

[10] Antràs, Pol, and Elhanan Helpman (2004). Global Sourcing, Journal of Political Economy, 112, pp. 552.580 .

[11] Antràs, Pol, and Elhanan Helpman (2008). Contractual Frictions and Global Sourcing, forthcoming in E. Helpman, D. Marin, and T.
Verdier (eds.), The Organization of Firms in a Global Economy, Harvard University Press.

[12] Magnus Blomstrom(1986).Foreign Investment and Productive Efficiency: The Case of Mexico, Journal of Industrial Economics, 35:1, pp.97-110.

[13] Magnus Blomstrom and Hakan Persson(1983). Foreign investment and spillover efficiency in an underdeveloped economy: Evidence from the Mexican manufacturing industry, World Development,11:6, pp.493-501.

[14] Ari Kokko (1994). Technology, market characteristics and spillover, Journal of Development Economics, 43: 2, pp.279-293.

[15] Magnus Blomstrom and Fredrik Sjoholm(1999). Technology transfer and spillover: Does local participation with multinationals matter, European Economic Review,43:4-6, pp.915-923.

[16] Aitken, B., Harrison, A., (1999). Do domestic firms benefit from direct foreign investment? Evidence from Venezuela. American Economic Review, 89 (3), 605-618.

[17] Mihir A. Desai, C. Fritz Foley and James R. Hines Jr.(2005). Foreign Direct Investment and the Domestic Capital Stock, American Economic Review, 95(2), 33-38.

[18] Yang Li and Jinli Hu, (2010) R\&D, FDI, and Efficiencies of Small and Medium-sized Firms, Journal of Management Research,13(3), pp.163179

[19] Jaya Prakash Pradhan and Neelam Singh(2009). Outward FDI and Knowledge Flows: A Study of the Indian Automotive Sector, International Journal of Institutions and Economies, 1(1), pp.156-187.

[20] Bruce Blonigen (1997). Firm-Specific Assets and the Link between Exchange Rates and Foreign Direct Investment, American Economic Review, 87(3), 447-65.

[21] Horstman \& Markusen (1992). Endogenous market structures in international trade, Journal of International Economics, 32(1-2), 109-129.

[22] Feenstra R C, Huang DS, Hamilton G G. A marketpower based model of business groups[J]. Journal of Economic Behavior \& Organization, 2003, 51(4):459-485.

[23] Carr, David L., James R. Markusen, and Keith E. Maskus (2001). Estimating the Knowledge-Capital Model of the Multinational Enterprise, American Economic Review, Vol. 91, No. 3, pp. 693-708.

[24] Hymer, Stephen H. The International Operations of National Firms: A Study of Direct Foreign 
Investment[J]. Journal of International Business Studies, 1978.

[25] Peter Buckley and Mark Casson (2016). The Future of the Multinational Enterprise. The Macmillan Press Ltd.

[26] John H.Dunning (1977). Trade, Location of Economic Activity and the MNE: A Search for an Eclectic Approach, pp 395-418.

[27] Louis T Wells. The Internationalization of Firms from Developing Countries[M]. Cambridge, MA: MIT Press, 1977.

[28] Lall S, Wiley (1985). The New Multinationals: The Spread of Third World Enterprises, New Multinationals Spanish Firms in A Global Context.

[29] John A Cantwell. Techological Innovation and Multinational Corporations. Oxford: Basil Blackwell. and Paz Estrella E. Tolentino (1990). Technological Accumulation and Third World Multinationals. Discussion Paper No. 139, Department of Economics, University of Reading, Series B, III.

[30] Guangqin Xiong, Yufei Yin (2014). Location choice of FDI in Western China: 1998-2011 [J]. Economics Exploration (9):62-67.

[31] Mody, A., and K. Srinivasan. Japanese and U.S. Firms as Foreign Investors: Do They March to the Same Tune $[\mathrm{J}]$. Canadian Journal of Economics, 1998, 31(4): 778-799.

[32] Akinlo, A. E. Foreign Direct Investment and Growth in Nigeria: An Empirical Investigation [J]. Journal of Policy Modeling, 2004, 26(5):627-639.

[33] Wang, Z. Q., and N. Swain. Determinants of Inflow of Foreign Direct Investment in Hungary and China: Time-Series Approach[J]. Journal of International Development, 1997,9(5):695-726.

[34] Dube, A., T. W. Lester, and M. Reich. Minimum Wage Effects Across State Borders: Estimates Using Contiguous Counties[J]. Social Science Electronic Publishing,2010,92(4):945-964.

[35] Shuang Ma, Zhe Zhang, Xi Zhu. The impact of minimum wage on employment and wage level in China. Economics Review, 2012, (5):132-146.

[36] Zhimin Duan, Feng Hao (2019), Research on the income distribution effect of minimum wage policy in urban families. Statistics Review, (7):65-76.

[37] Jun Zhang, Da Zhao, Longfei Zhou (2017). The influence of minimum wage standard increase on employment normalization. China's industrial economy, (1): 83-99. 